Ryokichi Goto MD, Howard Tearle ACT RLAT, David J. Steward MB FRCPC, Phillip G. Ashmore MD FRCSC

\section{Myocardial oedema and ventricular func- tion after cardioplegia with added mannitol}

cardioplégie et la quantité de liquide tissulaire présem au moment de la reperfusion était inversement proportionnelle à la performance ultérieure du ventricule. Nous avons ensuite étudié l'effet de l'ajout de mannitol à la solution crystallöide cardioplégiante. Nous avons cardioplégié les neuf caurs du groupe contrôle avec une solution standard (Plegisol ${ }^{\text {30 }}$ ) et arons ajouté du mannitol à celle de huit autres jusqu'à concurrence d'une osmolalité de $360 \mathrm{mOsml \leq} \cdot L^{-1}$. Dans le groupe mannitol, il y eut moins d' adème du ventricule droit et une meilleure $d P / d t_{\max }$ du ventricule gauche après reperfusion. Le mannitol augmente donc la protection myocardique pendanl l'arrêt cardiaque par cardioplégie.

Myocardial protection provided by cardioplegic solutions is incomplete and following reperfusion there is a period of depressed myocardial function.' Myocardial oedema may be a factor in this change in function, directly causing a reduction in compliance and contractility of the ventricles. ${ }^{2}$ In addition, oedema may compromise myofibrillar oxygenation resulting in poor immediate function and also long-term tissue damage.

Using an isolated heart model we have studied the rate of formation of oedema during cardioplegic-induced arrest and its relation to ventricular function. Further experiments were performed to determine whether the changes in function which were observed were to the tissue oedema or to other damaging mechanisms. In order to reduce tissue oedema during cardioplegia, mannitol was added to the cardioplegic solution to produce a hypertonic fluid $\left(360 \mathrm{mOsm} \cdot \mathrm{L}^{-1}\right)$. The effect of this modified solution on oedema formation and postreperfusion cardiac function as measured by $\mathrm{dP} / \mathrm{dt}_{\max }$ was assessed.

\section{Method}

Ten adult male rabbits (mean weight $2.36 \mathrm{~kg}$ ) were

*Plegisol (Abbott Labs, N. Chicago, Ill, U.S.A.) Contains $\mathrm{NaCl} 643 \mathrm{mg}, \mathrm{CaCl}_{2} 17.6 \mathrm{mg}, \mathrm{MgCl}_{2} 325.3 \mathrm{mg}, \mathrm{KCl} 119.3$ $\mathrm{mg}$ in each $100 \mathrm{ml}$ approximately equal $\mathrm{Na}=110 \mathrm{mEq} \cdot \mathrm{L}^{-1}$, $\mathrm{Cl} 160 \mathrm{mEq} \cdot \mathrm{L}^{-1}, \mathrm{~K} 16 \mathrm{mEq} \cdot \mathrm{L}^{-1}$, Ca $2.4 \mathrm{mEq} \cdot \mathrm{L}^{-1}, \mathrm{Mg} 32$ $\mathrm{mEq} \cdot \mathrm{L}^{-1}$. 


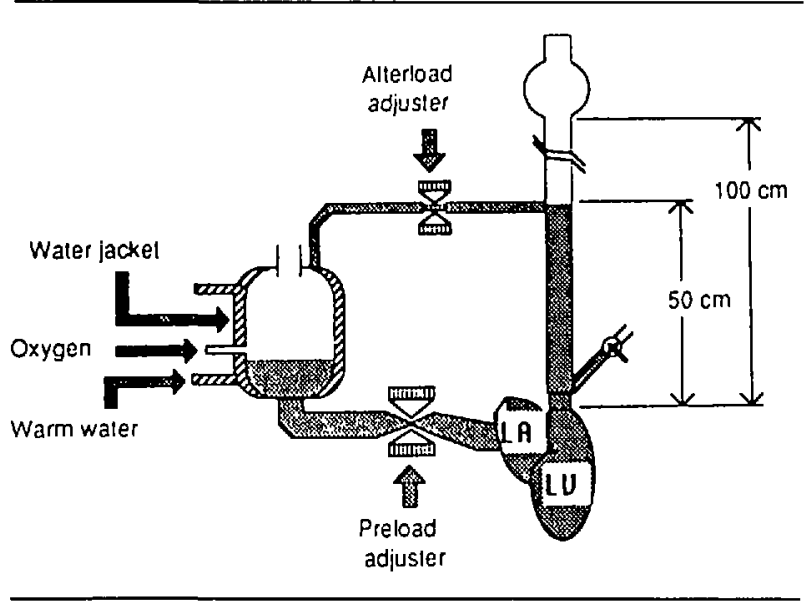

FIGURE 1 Diagram of apparatus. Warm oxygenated blood was supplied to the (L) atrium from a heated oxygenator/reservoir. The (L) ventricular afterload and the infusion pressure of the repeated doses of cardioplegia were adjusted by the height of fluid within the vertical column.

premedicated with $0.05 \mathrm{mg} \cdot \mathrm{kg}^{-1}$ diazepam, and anaesthetized using three per cent halothane and 66 per cent nitrous oxide. An intravenous line was established and blind tracheal intubation performed. The chest was opened using a bilateral transverse incision. Tapes were placed around the superior vena cava, inferior vena cava and aorta. Five minutes after the injection of sodium heparin ( $3 \mathrm{mg} \cdot \mathrm{kg}^{-1}$ ), the animals were bled to obtain sufficient blood to prime the apparatus circuit taking care that the systolic blood pressure was kept over $50 \mathrm{mmHg}$.

A double lumen cannula was inserted into the apex of the left ventricle of the beating heart and a small biopsy of the apex was taken and weighed. A small biopsy was also taken from the right ventricle and weighed. These and subsequent biopsies were then dried over two hours in a desiccator and reweighed to determine tissue water content. In rapid sequence the IVC and SVC were ligated and the distal part of the ascending aorta was clamped. Cold crystalloid cardioplegia (Plegisol ${ }^{(1)} 30 \mathrm{ml} \cdot \mathrm{kg}^{-1}$ was infused into the proximal part of the aorta. Cardioplegic solution returning to the right ventricle was drained through the biopsy site and the left ventricle was vented via the double lumen catheter. A repeat biopsy from the right ventricle was taken after the infusion of cardioplegia. The heart was removed with $2-3 \mathrm{~cm}$ of attached aorta and placed in cold saline. The aorta was then attached to a constant pressure infusion system which was essentially a vertical column (Figure 1). The pressure in the aortic root was monitored by the height of the blood or fluid inside the column.

Each experiment was continued as follows (Figure 2). A second dose of $30 \mathrm{ml} \cdot \mathrm{kg}^{-1}$ cardioplegic solution (CPS) was infused, monitoring the aortic root pressure, and maintaining it at $36 \mathrm{mmHg}$ which is nearly equal to the diastolic pressure of the anaesthetized rabbit. The left atrial cavity was connected via a tube to the blood reservoir-oxygenator and the openings of the pulmonary veins were sutured closed. Immediately after the second CPS infusion, while maintaining the aortic root pressure at $36 \mathrm{mmHg}$, the pressure inside the LV cavity was kept at $3 \mathrm{mmHg}$ by infusion of isotonic saline through the LV catheter. The volume of the fluid which was required to increase the LV cavity pressure to $5 \mathrm{mmHg}$ was then measured. Subsequently the incremental volumes required to increase the intracavity pressure from 5 to 7,7 to 9,9 to 11 , and 11 to $13 \mathrm{mmHg}$ were measured. From these the compliance (C) at each $\mathrm{LV}$ cavity pressure was determined. A further RV biopsy was also taken for subsequent wet and dry weighing. Repeated myocardial biopsies were taken sequentially from progressively more proximal areas of the coronary circulation of the RV. A further infusion of $30 \mathrm{ml} \cdot \mathrm{kg}^{-1}$ cardioplegic solution followed by the same sequence of compliance measurements and RV biopsy was made after $20 \mathrm{~min}$. After a further $20 \mathrm{~min}$, a final RV biopsy was performed without infusion of cardioplegia. After the end of the procedure above, coronary perfusion pressure was adjusted to 36 $\mathrm{mmHg}$, and the heart was reperfused with warm $\left(37^{\circ} \mathrm{C}\right)$ oxygenated blood. Residual blood was evacuated from the left ventricle using the $\mathrm{LV}$ catheter as a vent tube to allow for an empty beating recovery period of 15 minutes. After this recovery period, the $L V$ filling pressure was increased progressively and the $L V$ function curve recorded and the $\mathrm{dP} / \mathrm{dt}_{\max }$ was measured. At the end of the experiment, another biopsy was taken from the LV apex and weighed in the wet and dry condition.

A further 17 adult male rabbits were randomly divided into two groups "control" (nine animals) and "mannitol" (eight animals). The heart was isolated and prepared as described above. In the control group, cardioplegic arrest was induced by $30 \mathrm{ml} \cdot \mathrm{kg}^{-1}$ Plegisol ${ }^{\circledR}\left(280 \mathrm{mOsmol} \cdot \mathrm{L}^{-1}\right)$. In the mannitol group, powdered mannitol was first added to Plegisol ${ }^{\circledR}$ to produce a solution with an osmotic pressure of $360 \mathrm{mOsmol} \cdot \mathrm{L}^{-1}$ ). The volume of cardioplegic solution per $\mathrm{kg}$ body weight was identical in both groups. The subsequent sequence of measurements was continued as in the previous experiments (Figure 2). Statistical analysis was performed using regression analysis and Student's t tests, where applicable.

\section{Results}

In the initial experiments (ten animals), tissue water content increased progressively throughout the experiment (Figure 3). The left ventricle compliance curves measured after the second and third infusion of cardioplegia showed some significant differences (Figure 4): 


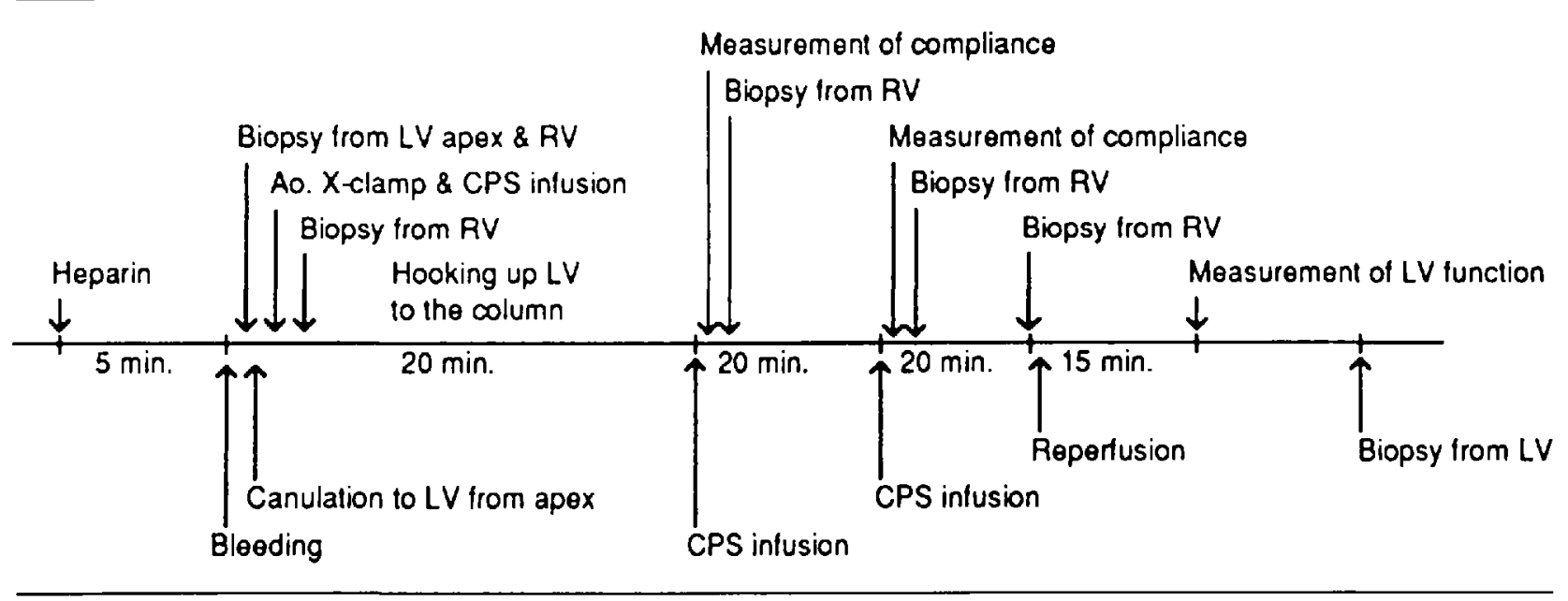

FIGURE 2 Sequence of each experiment (see text for details).

compliance at lower ventricular pressures (i.e., lower volumes) decreased significantly between the second and third infusion of cardioplegia. There was no change in compliance at filling pressures above $7 \mathrm{mmHg}$. The $\mathrm{LV}$ compliance measured at low LV volume ( $\mathrm{LV}$ compliance measured at pressure 3 to 5 and 5 to $7 \mathrm{mmHg}$ ) and the maximal value of $\mathrm{dP} / \mathrm{dt}_{\max }$ post-reperfusion showed significant correlation (Figure 5).

Myocardial (RV) water content prior to reperfusion showed significant correlation with $\mathrm{dP} / \mathrm{dt}_{\max }$ when the heart resumed beating (Figure 6 ). The change in $R V$ water content between the first sample and that taken at the end of hypothermic cardioplegic cardiac arrest showed significant correlation with $\mathrm{dP} / \mathrm{dt}_{\text {max }}$ (Figure 7). However, the change in LV water content between the biopsy taken

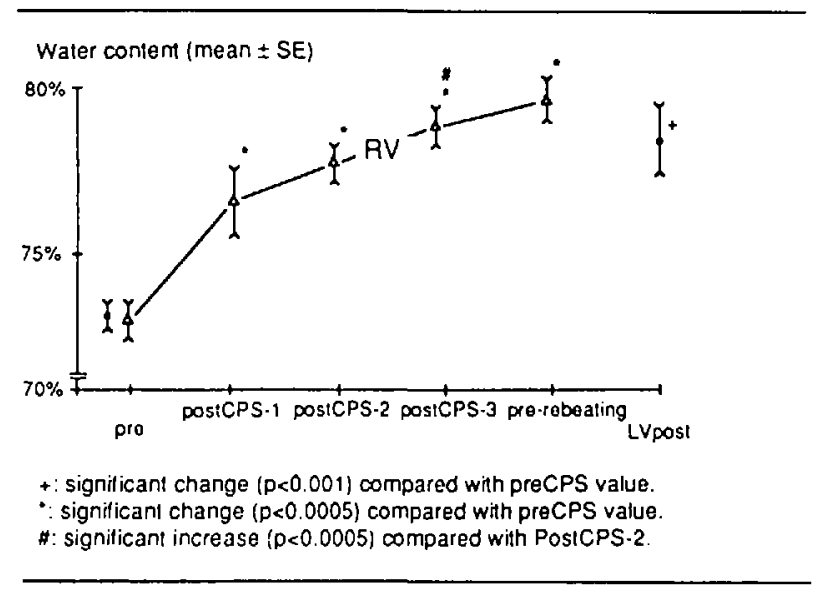

FIGURE 3 Changes in myocardial water content during and following cardioplegia: $\Delta=\mathrm{RV}$ water content; $\boldsymbol{\nabla}=\mathrm{LV}$ water content. Post-CPS I,2,3 = value after first, second and third infusion of cardioplegia solution. Pre-rebeating $=$ value immediately before reperfusion. before removal of the heart and that taken at the end of the experiment (i.e., after 30 min of rebeating) showed no significant correlation with $\mathrm{dP} / \mathrm{dt}_{\text {max }}$ (Figure 7).

In the second set of experiments the values for body weight, cardioplegic solution temperature, blood temperature and haematocrit following reperfusion are shown in Table I. There were no significant differences of any of these variables between the two groups and there was no correlation of post-reperfusion $\mathrm{dP} / \mathrm{dt}_{\max }$ with any of these factors.

In both groups there was a significant increase in the water content of serial tissue samples. The progression of tissue water content, and the differences between the two groups are shown in Figure 8. While there was no difference between the two groups before cardioplegia, or after the first and second infusion of CPS, the difference was

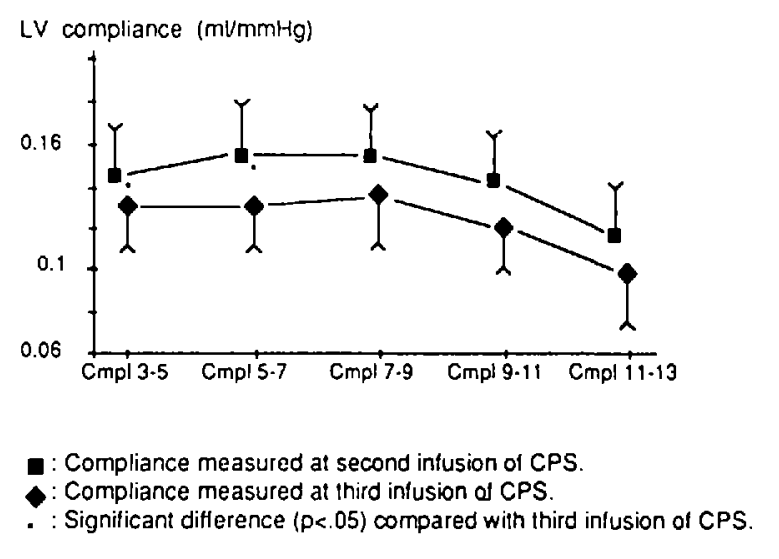

FIGURE 4 Compliance of the (L) ventricular measured after the second and third infusion of cardioplegia solution. CMPL 3-5, $5-7,7-9 \mathrm{ctc} .=$ compliance measured between intraventricular pressures of 3-5 mmHg, $5-7 \mathrm{mmHg}, 7-9 \mathrm{mmHg}$ etc. 


\section{$\mathrm{dP} / \mathrm{dt} \max \mathrm{mmHg} / \mathrm{s} \theta \mathrm{C}$}

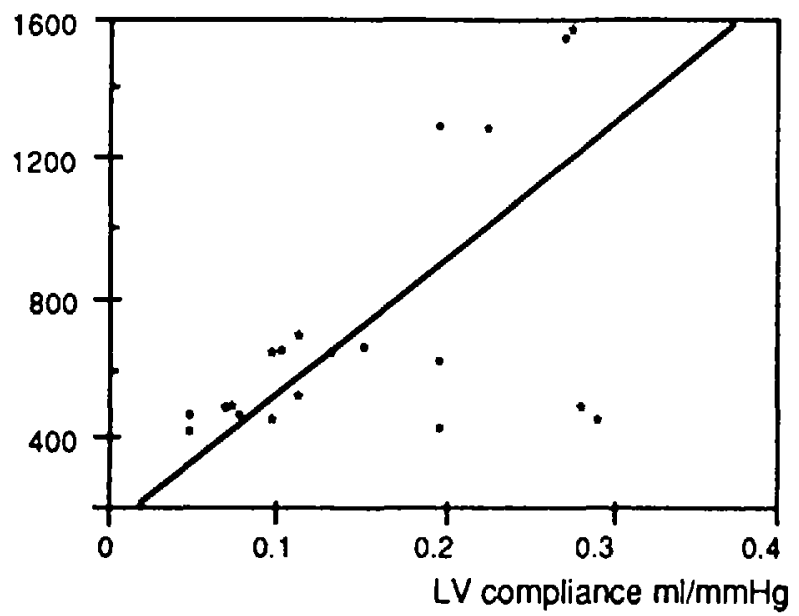

- $C_{1}(3.5)$

- $C_{1}(5-7)$

- Regression line of $\mathrm{C} 1(3.5)$
$\mathrm{dP} / \mathrm{dt}$ max $\mathrm{mmH} / \mathrm{sec}$

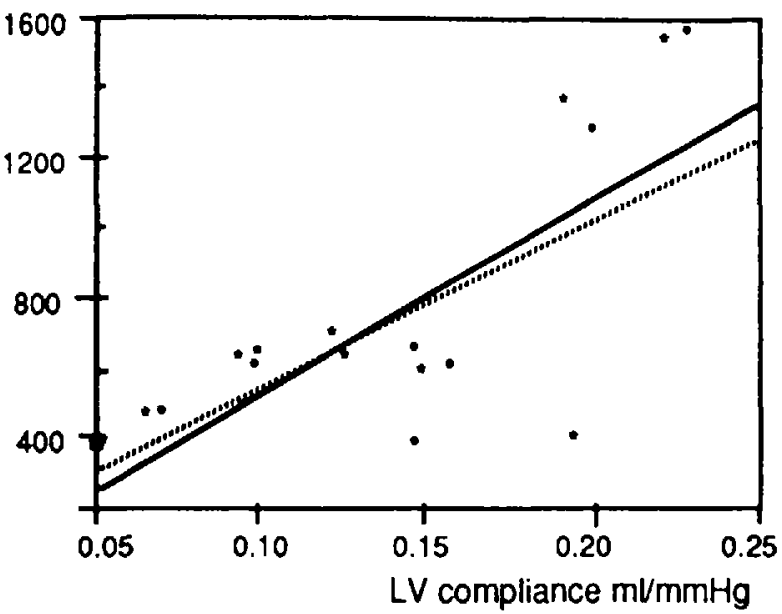

- $\mathrm{C} 2(3-5)$

- $\mathrm{C} 2(5-7)$

- Regression line of C2(3-5)

....... Regression line of C2(5-7)

FIGURE 5 Relationship of $\mathrm{dP} / \mathrm{dt} t_{\max }$ after reperfusion with the $\mathrm{LV}$ compliance after first and second compliance measured between intraventricular pressures of 3-5 and 5-7 mmHg after the first (C1) and Second (C2) infusion of cardioplegia. (Regression line C2 (3-5) coefficient of correlation $=0.83 P=0.005$ ).

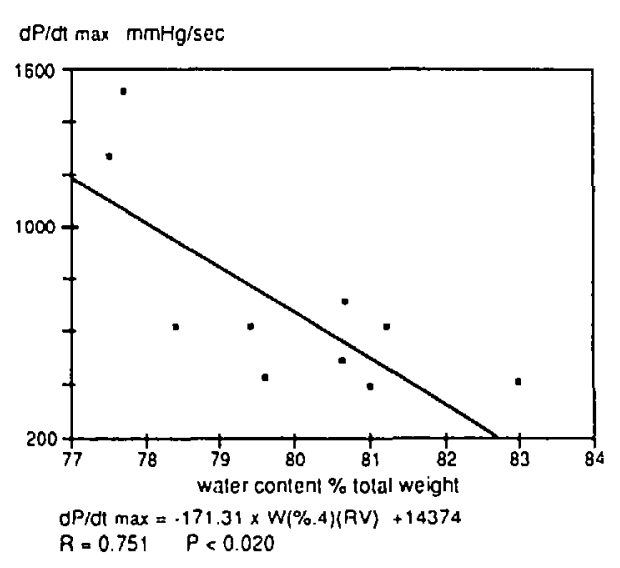

FIGURE 6 Relation between RV myocardial water conten immediately before reperfusion and subsequent $\mathrm{LV} \mathrm{dP} / \mathrm{dt}$ of the reperfused heart.

significant after the third infusion, and immediately before reperfusion. The tissue water content of the mannitol group was lower.

There were no significant differences in LV compliance at any time between the two groups. But, as in the previous studies, within each group the progressive change in compliance between the first and second measurement was significant at lower ventricular volume.

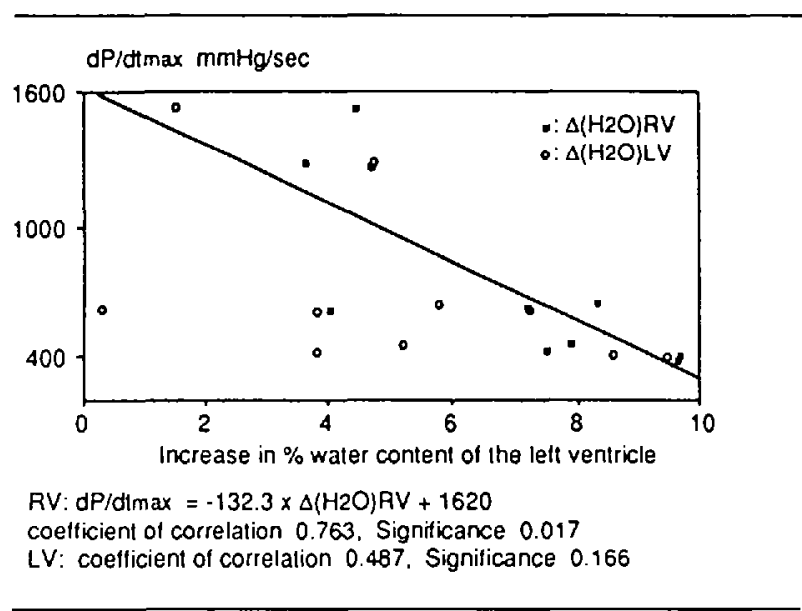

FIGURE 7 Relation between per cent increase in LV and RV water content and subsequent $L V \mathrm{dP} / \mathrm{dt}_{\max }$ after reperfusion.

No correlation between the LV compliance and any measurement of the tissue water content was detected.

In each group, tissue water content at each biopsy and subsequent $\mathrm{dP} / \mathrm{dt}_{\max }$ of the beating heart were examined by regression analysis. The $\mathrm{dP} / \mathrm{dt}_{\max }$ and water content of the RV in both groups correlated well only for the biopsy sample taken just before reperfusion (Figures 9 and 10). A significant difference in the $\mathrm{dP} / \mathrm{dt}_{\text {max }}$ between the two 


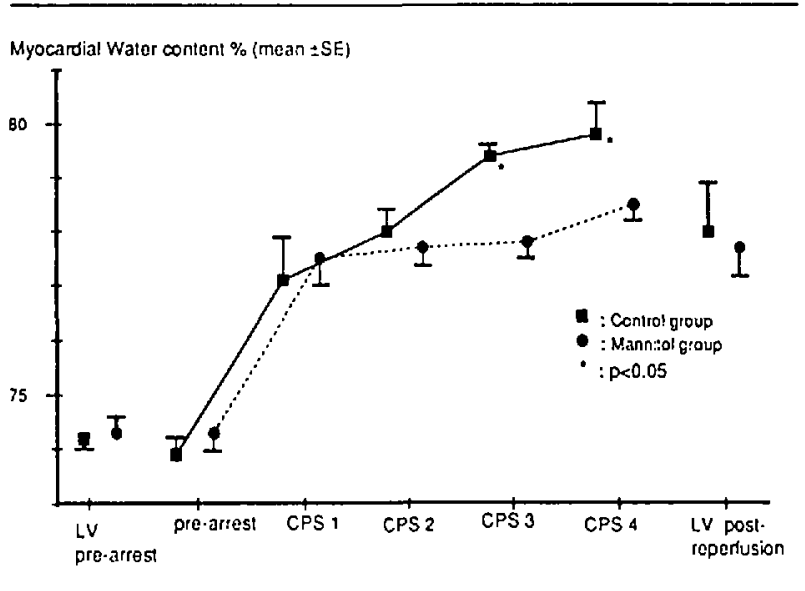

FIGURE 8 The increase in myocardial waler content in the control and mannitol groups of animal during the experiments. LV water content was measured only at the start and at the end of the experiment. RV water content was measured pre-arrest, after the first, sccond and third infusion of cardioplegia (CPS $1,2,3$ ) and immediately before reperfusion (CPS 4).

groups was detected (Table II), the mannitol group showing evidence of better LV function.

\section{Discussion}

These experiments have demonstrated that the administration of cardioplegic solution is followed by myocardial oedema, and that this oedema is associated with changes in function of the ventricle. Myocardial oedema has previously been shown to be associated with changes in myocardial function, ${ }^{3}$ although in some of these studies the methods used to produce oedema (e.g., administration of norepinephrine) might be expected also to cause myocardial damage. The state of myocardial hydration is recognized as an important determinant of function, indeed both oedema and dehydration have been shown to have detrimental effects on myocardial function. ${ }^{4}$ Pogátsa et al. ${ }^{3-7}$ studied the effects of myocardial water content

TABLE I Comparison of experimental conditions between the two groups of animals (unpaired $t$ test)

\begin{tabular}{llllll}
\hline & & Mean & SEM & OBS & Significance \\
\hline Body weight $(\mathrm{kg})$ & $\mathrm{C}$ & 2.63 & 0.10 & 9 & NS \\
& $\mathrm{M}$ & 2.49 & 0.10 & 8 & \\
Temp. cardioplegia & $\mathrm{C}$ & 9.22 & 0.86 & 9 & NS \\
solution $\left({ }^{\circ} \mathrm{C}\right)$ & $\mathrm{M}$ & 7.06 & 1.12 & 8 & \\
Temp. blood at & $\mathrm{C}$ & 36.27 & 0.22 & 9 & NS \\
reperfusion $\left({ }^{\circ} \mathrm{C}\right)$ & $\mathrm{M}$ & 36.03 & 0.12 & 8 & \\
Hct $(\%)$ of blood & $\mathrm{C}$ & 24.50 & 0.32 & 9 & NS \\
& $\mathrm{M}$ & 26.81 & 1.23 & 8 & \\
\hline
\end{tabular}

$\mathrm{C}=$ control group $\mathbf{M}=$ mannitol group

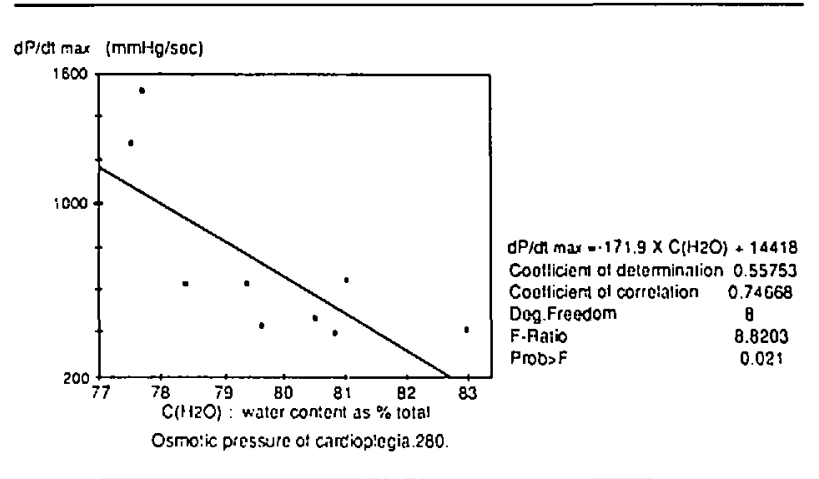

FIGURE 9 Relationship between RV myocardial water content $\left(\mathrm{C}\left(\mathrm{H}_{2} \mathrm{O}\right)\right)$ measured immediately before reperfusion and subsequent $\mathrm{dP} / \mathrm{dt}_{\max }$ max of the $\mathrm{LV}$ in the control group of animals.

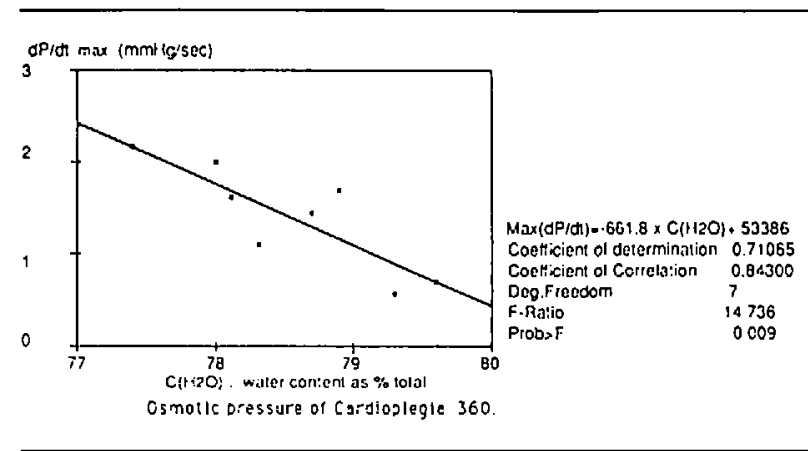

FIGURE 10 Relationship between the RV myocardial water content $\left(\mathrm{C}\left(\mathrm{H}_{2} \mathrm{O}\right)\right)$ immediately before reperfusion and subsequent $\mathrm{dP} / \mathrm{dt}_{\max }$ in the animals in which mannitol was added to the cardioplegia solution.

on left ventricular stiffness, but the changes in water content were produced by methods (e.g., norepinephrine) which might also cause tissue damage. They employed quite different methods to induce dehydration or oedema

TABLE II Coefficient of correlation of $\max (\mathrm{dP} / \mathrm{dt})$ after reperfusion and the LV compliance after the second and thind infusion of cardioplegia

Compliance measured after the second infusion of the cardioplegia

\begin{tabular}{llllll}
\multicolumn{5}{c}{ Intraventricular pressure } \\
\cline { 2 - 6 } & $3-5 \mathrm{~mm}$ & $5-7 \mathrm{~mm}$ & $7-9 \mathrm{~mm}$ & $9-1 / \mathrm{mm}$ & $11-13 \mathrm{~mm}$ \\
\hline Coeff/correl & 0.735 & 0.564 & 0.547 & 0.363 & 0.132 \\
Significance & NS & NS & NS & NS & NS
\end{tabular}

Compliance measured after the third infusion of the cardioplegia

\begin{tabular}{lccccc}
\multicolumn{6}{c}{ Intraventricular pressure } \\
\cline { 2 - 6 } & $3-5 \mathrm{~mm}$ & $5-7 \mathrm{~mm}$ & $7-9 \mathrm{~mm}$ & $9-1 / \mathrm{mm}$ & $11-13 \mathrm{~mm}$ \\
\hline Coeff/correl & 0.834 & 0.731 & 0.314 & 0.185 & 0.129 \\
Significance & $<0.01$ & $<0.05$ & NS & NS & NS \\
\hline
\end{tabular}


of the muscle making it difficult to relate their results to the problem of oedema secondary to infusion of cardioplegic solution.

The cause of myocardial oedema during cardioplegic arrest is not limited to an osmotic effect of the solution, but may also result from the ischaemic condition of the myocardium. ${ }^{8}$ Simple ischaemia causing myocardial oedema has been observed and reported by Rosenkranz et al., ${ }^{9}$ and is explained by the accumulation of products of anaerobic metabolism leading to increased intracellular osmotic pressure. ${ }^{10}$ The intracellular osmotic pressure is reported to increase by $100 \mathrm{mOsml} \cdot \mathrm{L}^{-1}$ during the first 120 min of ischaemia, but swelling of the myocardial cell is restricted, ${ }^{12}$ as under such conditions cell swelling reflects merely the movement of water from extracellular to the intracellular space. ${ }^{12,13}$ During cardioplegia accumulation of intracellular metabolites also occurs and the increase in total tissue water content is equal to the volume of water absorbed from the CPS.

In this study, the changes in water content of the RV muscle following the use of a CPS of a fixed osmotic pressure were measured, and related to the degree of

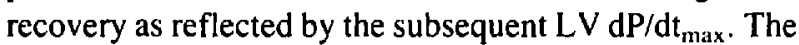
heart was reperfused with diluted blood which had an osmotic pressure of approximately $280 \mathrm{mOsm} \cdot \mathrm{L}^{-1}$, little different from that of the cardioplegic solution (Plegis$\left.\mathrm{ol}^{\circledast}\right)$. The rate of change in water content (Figure 3 ) during cardioplegic cardiac arrest reflects the rapidity of the accumulation of metabolites affecting intracellular osmolality, " and the availability of free water in the extracellular compartment. Initially water content increases rapidly, then more slowly as the metabolism of the cell decreases and the availability of water to pass into the intracellular space becomes limited.

Prior to CPS-induced arrest the water content of both ventricles was similar, varied little in different experiments, and had no correlation with the subsequent $\mathrm{dP} /$ $\mathrm{dt}_{\max }$. This suggests that the preparation of the experiment was done under uniform conditions, and that any myocardial damage incurred during preparation was similar in all hearts. The value of $\mathrm{dP} / \mathrm{dt}_{\max }$ measurements in the assessment of myocardial contractility may be questioned if changes in heart rate, preload, or afterload occur. ${ }^{14}$ In the described experiments the heart was isolated and denervated and was beating at a constant rate. During measurements of $\mathrm{dP} / \mathrm{dt}_{\max }$ the preload and afterload were adjusted to standard values and all experiments were performed under identical conditions. Hence it is assumed that the changes in $\mathrm{dP} / \mathrm{dt}_{\text {max }}$ which were observed are valid. The $L V \mathrm{dP} / \mathrm{dt}_{\text {max }}$ measured after the heart resumed beating (Figure 6) was inversely related to the water content of RV myocardium after $60 \mathrm{~min}$ of cardioplegic cardiac arrest. It was not possible to take a $\mathrm{LV}$ biopsy at this time without compromising further studies of $\mathrm{LV}$ function. The change in LV water content measured after the end of the experiment correlated poorly with LV $\mathrm{dP} / \mathrm{dt}_{\text {max }}$ after reperfusion, though the latter had shown good correlation with RV end-arrest water content. The condition during CPS arrest is similar in RV and LV tissue unless coronary perfusion is disturbed. During recovery, however, and after reperfusion and with spontaneous activity LV tissue oedema may increase or decrease, explaining the lack of correlation of terminal LV water content with $\mathrm{dP} / \mathrm{dt}$ after reperfusion. Thus $\mathrm{RV}$ water content at the end of cardioplegic arrest may better reflect the pre-reperfusion LV myocardial condition than the terminal LV biopsy.

Left ventricular compliance measurements have commonly been made by introducing a highly compliant balloon. $^{2-8,15,16}$ However, the possibility that such a balloon, even though compliant, might affect the measurements and cannot be discounted. In this study, a balloon was not used as it was found that the mitral and aortic valves were competent even in the isolated organ, provided the heart was not distorted. Care was taken to avoid any distortion of the heart during measurement of compliance. While maintaining the aortic pressure at over $36 \mathrm{mmHg}$ and with a left intraventricular pressure of about $8 \mathrm{mmHg}$ we also found that flow via the besian veins into left ventricle during the period of measurement ${ }^{17}$ was negligible; that is, no progressive increase was seen in left ventricular cavity pressure. Hence we consider our method for the measurement of compliance to be justified.

Oedema has been reported to cause a decrease in the compliance of the diastolic ventricle,$^{3,5-8.15}$ requiring higher preload to maintain the same stroke volume. In the isolated heart preparation, cardiac function at a given preload can be evaluated by measuring compliance in addition to contractility. There was a significant reduction of the LV compliance at low LV pressure (from 3 to 5 , $\mathrm{mmHg}$ and from 5 to $7 \mathrm{mmHg}$ ) between the first and second measurements; i.e., after the second and third infusion of cardioplegia. We were, however, unable to demonstrate significant correlation between the reduction in compliance and the increase in myocardial water content of individual hearts.

Maximal value of $\mathrm{dP} / \mathrm{dt}_{\text {max }}$ after reperfusion showed close correlation with $\mathrm{LV}$ compliance measured at low $\mathrm{LV}$ pressure ( 3 to $5 \mathrm{mmHg}$ ) following the third CPS infusion (Table II). There are many reports of the relationship between myocardial function and LV compliance ${ }^{3-8.12,13,16.17}$ based on experiments in which the decrease in LV compliance was induced by relative or absolute ischaemia 
caused by coronary ligation, myocardial overwork or CPS arrest. In our experiments, the LV compliance measured at low and higher pressure showed different results. At low $\mathrm{LV}$ pressure the change in compliance correlated well with change in $\mathrm{dP} / \mathrm{dt}$, but no correlation was demonstrated at high LV pressure. This may be due to the change in thickness of the ventricular wall as the LV was inflated, and the relatively lesser effect of changes in myocardial stiffness at higher ventricular volumes.

In summary an increase in myocardial water content was observed during cardioplegic cardiac arrest. The rate of the increase was most rapid immediately after cardioplegic arrest, and subsequently diminished. The final RV water content measured just before reperfusion demonstrated good correlation with post-arrest $\mathrm{LV}$ myocardial function, increased water content associated with more severely impaired function.

The second set of experiments was designed to investigate the modifying influence of a mannitol on this process. In these experiments the increase in tissue water content toward the end of cardioplegic arrest was higher in the control group than in the mannitol group. However, the observed difference between the two groups was relatively small when compared to the progressive increase in tissue water of all hearts of both groups during cardioplegia.

The progressive increase in tissue water during cardioplegia, which is only slightly modified by the addition of mannitol, suggests that the oedema is principally a result of factors other than the osmolality of the CPS perfusate, principally the accumulation of anaerobic metabolites in the myocardium. Several reported studies of myocardial oedema support this theory. They detail the morphology, ${ }^{12}$ the effect of hypoxia and ischaemia, ${ }^{20}$ and the changes in ultrastructure of myocardial cells. ${ }^{13.21}$ Buja et al. ${ }^{22}$ observed that there was an association between disruption of the myocardial cell membrane and myocardial oedema, caused by the osmotic load of the products of anaerobic metabolism. They concluded that cell swelling could be at least partially reversed by the direct osmotic effects of the perfusate. ${ }^{22}$ On the other hand the direct deleterious effect of hypotonic perfusates resulting in myocardial oedema was reported by Steenbergen $e t$ al. $^{21}$ They used electron microscopy and measurcments of insulin-diffusible space to monitor plasma membrane integrity in their experiments. They concluded that cell swelling, as a result of osmotic diffusion, was normally incapable of rupturing the plasma membrane, normal myocytes could tolerate a 50 per cent increase in cell water without rupturing cell membranes. However, after prolonged periods of energy deficiency as might occur during ischaemia or reperfusion, the plasma mem-
TABLE III Comparison of $\max (\mathrm{dP} / \mathrm{dt})$ after reperfusion between control and mannitol groups (unpaired $t$ test)

\begin{tabular}{lcc}
\hline & Control group & Mannitol \\
\hline Mean & 705.56 & 1410.63 \\
SEM & 135.72 & 201.75 \\
Observations & 9 & 8 \\
\hline
\end{tabular}

$P<0.05$

brane or its cytoskeletal scaffold becomes injured. This compounds the damage of oedema when it allows the membrane of the swollen cell to rupture. Thus during cardioplegic arrest oedema may occur, probably as a result of accumulation of metabolites, but this may be modified to some extent by the osmotic effect of the perfusate.

We measured the LV compliance twice, after the second and third infusion of cardioplegia. We found no significant difference between the two groups in $\mathrm{LV}$ compliance at any $\mathrm{LV}$ volume. On the other hand, in both groups, as in the initial experiments, the LV compliance at low volume decreased during cardioplegia. This was not due to increased tissue water as there was no correlation between the change in compliance and myocardial water content. Rather this must be an effect of other tissue changes which accompany cardioplegia.

In both groups of experiments there was a correlation between $\mathrm{dP} / \mathrm{dt}_{\text {max }}$ after reperfusion and $\mathrm{RV}$ water content measured just before reperfusion (Table III). In addition, there was a significant difference between the two groups in $\mathrm{dP} / \mathrm{dt}_{\text {max }}$ after reperfusion. As the procedures employed in the two groups were otherwise similar, this difference must be related to the addition of mannitol, which resulted in improvement in $\mathrm{dP} / \mathrm{dt}_{\max }$. What are the possible mechanisms for this effect? The mannitol group did show a lower tissue water content immediately before reperfusion. Therefore this improvement in $\mathrm{dP} / \mathrm{dt}_{\text {max }}$ may be an osmotic effect of limiting tissue oedema. On the other hand, these results may also be due to other effects of mannitol which may improve myocardial function. Mannitol is an oxygen radical scavenger ${ }^{23}$ and Ouriel et al. suggested that the effect of mannitol may be due to this mechanism. ${ }^{8}$ McDonough et al. examined the effects of oxygen radicals on substrate oxidation by cardiac myocytes. ${ }^{24}$ They reported that the oxidation of exogenous glucose, lactate and octanoate was severely inhibited (approximately 70 per cent) by products of xanthine oxidase activity and superoxide dismutase plus catalase effectively prevented the inhibition of oxidation. Further experiments will be required to assess the role of oxygen radical scavenging by mannitol versus its osmotic effects 
in producing enhanced myocardial protection during cardioplegia.

We conclude that cardioplegia-induced cardiac arrest leads to increased myocardial water content, and impaired myocardial function. This is at least partially inhibited by the addition of mannitol to the crystalloid cardioplegia. The mechanism of action of mannitol is unclear but may not be due solely to its osmotic effects.

\section{References}

I Conti VR, Bertranov EG, Blackstone EH. Kirklin JW. Digerness $S B$. Cold cardioplegia versus hypothermia for myocardial protection: randomized clinical study. J Thorac Cardiovase Surg 1978, 76: 577-89.

2 Foglia RP, Steed DL, Follet DM, Derland E, Buckberg $G D$. Iatrogenic myocardial cdema with potassium cardioplegia. J Thorac Cardiovase Surg 1979, 78: 217-2.

3 Pogátsa G, Koltai MZ, Grósz G. The role of the myocardial water content in heart function. Acta Physiol Hung 1982, 59: 305-9.

4 Pogátsa $G$, Dubecz $E$. The influence of hyperosmolality on heart function. Experimentia 1978; 34: 1600-2.

5 Pogatsa G, Dubecz $E$. The effect of hyperosmotic mannitol and glucose on heart function. Endokrinologic 1979; 73: 328-5.

6 Pogátsa $G$, Dubecz $E$, Gábor $G$. Effects of enhanced coronary flow during cardiopulmonary bypass: development of myocardial oedema. Basic Res Cardiol 1978: 73: $551-8$.

7 Pogársa $G$, Dubecz $E$, Gábor $G$. The role of myocardial edema in the left ventricular diastolic stiffness. Basic Res Cardiol 1976; 71 : 263-9.

8 Ouriel K, Ginsburg ME, Patti CS, Pearce FJ, Hichs GL. Preservation of myocardial function with mannitol reperfusate. Circulation 1985; (suppl II): 254-8.

9 Rosenkranz ER, Vinten-Johansen J, Buckberg GD, Okamoto F. Edwards $H$, Bugyi $H$. Benefits of normothermic induction of blood cardioplegia in energy-depleted hearts. with maintenance of arrest by multidose cold blood cardioplegic infusions. J Thorac Cardiovasc Surg 1982; 84: 667-77.

10 Leaf A. Cell swelling. Circulation $1973 ; 48: 455-8$.

11 Braasch W, Gudbjarnason S, Puri PS, Ravens KG, Bing $R J$. Early changes in energy metabolism in the myocardium following acute coronary artery occlusion in anesthetized dogs. Circ Res 1968; 23: 429-38.

12 Tranum-Jensen J, Janse MJ, Fiolet JWT, Krieger WJG, $D^{\prime}$ alnoncourt $C N$, Durrer $D$. Tissue osmolarity, cell swelling, and reperfusion in acute regional myocardial ischemia in the isolated porcine heart. Circ Res 1981; 49: 364-81.
13 Jennings RB, Steenbergen $C J r$. Nuclcotide metabolism and cellular damage in myocardial ischemia. Annu Rev Physiol 1985; 47: 727-49.

14 Mason DT. Uscfulness and limitations of the rate of rise of intraventricular pressure (dp/dt) in the evaluation of myocardial contractility in man. Am J Cardiology 1969; 23: 516-27.

15 Lazar HI, Buckberg GD, Foglia RP, Manganaro AJ, Maloney $J V$. Detrimental effects of premature use of inotropic drugs to discontinue cardiopulmonary bypass. $J$ Thorac Cardiovasc Surg 1981; 82: 18-25.

16 Grossman W, McLaurin LP. Diastolic properties of the left ventricle. Ann Intern Med 1976; 84: 316-26.

17 Faxon DP, Jacobs AK. Kellett MA, MCSweeney SM, Coats WD, Ryan TJ. Coronary sinus occlusion pressure and its relation to intracardiac pressure. Am J Cardiol 1985; 56: 457-60.

18 Hood WP. Amende I, Simon R. Lichten PR. The effcct of intracoronary nitroglycerine on left ventricular systolic and diastolic function in man. Circulation 1980; 61: 1098- 104.

19 Diamond G. Forrester JS. Effect of coronary artery discase and acute myocardial infarction on left ventricular compliance in man. Circulation 1972; 45: 11-9.

20 Jennings RB, Hawkins HK, Lowe JE, Hill ML. Klotman S, Reimer $K A$. Relation between high energy phosphate and lethal injury in myocardial ischemia in the dog. Am J Pathol 1978; 92: 187-214.

21 Steenbergen $C$, Hill $M L$, Jennings $R B$. Volume regulation and plasma membrane injury in aerobic, anacrobic, and ischemic myocardium in vitro. Effects of osmotic cell swelling on plasma membrane integrity. Circ Res 1985 ; 57: 864-75.

22 Buja LM, Willerson JT. Abnormalities of volume regulation and membrane integrity in myocardial tissue slices after early ischemic injury in the dog. Effects of mannitol, polyethylene glycol, and propranolol. Am J Pathol 1981; 103: 79-95.

$23 \mathrm{McCord} J M$, Fridovich I. Production of $\mathrm{O}_{2}{ }^{-}$in photolyzed water demonstrated through the use of superoxide dismutase. Photochem Photobiol 1973; 17: 11.5-21.

24 McDonough KH, Henry JJ, Spitzer JJ. Effects of oxygen radicals on substrate oxidation by cardiac myocytes. Biochimica et Biophysica Acta 1987; 926: 127-31. 